DOI 10.37882/2223-2982.2021.05.15

\title{
КИТАЙСКИЕ ЖИВОТНЫЕ В АСПЕКТЕ МЕЖКУЛЬТУРНОЙ КОММУНИКАЦИИ НА ЭЛЕКТРОННОЙ ПЛАТФОРМЕ ОН-ЛАЙН КОЛЛАБОРАЦИИ
}

\section{CHINESE ANIMALS IN THE ASPECT OF INTERCULTURAL COMMUNICATION ON THE ELECTRONIC PLATFORM OF ONLINE COLLABORATION}

\section{N. Zavyalova LiXinqi \\ Yuan Mengmeng}

Summary: The article is part of a research program aimed at promoting the Chinese language and culture in educational areas of a non-philological profile. The authors propose a series of lessons on the comparison of animalistic images in Chinese and English using the electronic platform for on-line collaboration "Miro board" in the context of distance learning. Individual and group work modes are presented. Integration of modern electronic services into the process of teaching Chinese is not exclusively a necessity dictated by the pandemic but is a goal the achievement of which makes the educational process more effective, fruitful, and adequate to modern business realities.

Keywords: China, animals, online, collaboration, intercultural communication.
Завьялова Наталья Алексеевна

Д.культурологии, к.филол.н., дочент, ФГБОУ «Уральский государственный экономический университет»

n.zavzav@yandex.ru

Ли Синьци

аспирант, ФГАОУ ВО «УрФУ имени первого Президента России Б.Н. Ельцина»

Юань Мэнмэн

аспирант, ФГАОУ ВО «УрФУ имени первого Президента России Б.Н. Ельцина»

Аннотация: Статья представляет собой часть исследовательской программы, направленной на продвижение китайского языка и культуры на образовательных направлениях нефилологического профиля. Авторы предлагают цикл занятий по сопоставлению анималистических образов в китайском и английском языках с использованием электронной платформы для он-лайн коллаборации «Miro board» в условиях дистанционного обучения. Представлены индивидуальный и групповой режим работы. Интеграция в процесс преподавания китайского языка современных электронных сервисов не является исключительно необходимостью, продиктованной пандемией, а представляет собой цель, достижение которой позволяет сделать учебный процесс более эффективным, плодотворным и адекватным современным бизнес реалиям.

Ключевые слова: Китай, животные, он-лайн, коллаборация, межкультурная коммуникация.

ный способ освоения современного мира, важнейшими детерминантами которого являются этническая гетерогенность, неоднородность населения, неравномерность развития общинного уклада, ведущая роль государства, скрепляющая общество религиозность. Целью овладения китайским языком в указанных программах мы считаем формирование когнитивных компетенций, обеспечивающих приток знаний о Китае [3]. Помимо познавательной активности изучение китайского языка направлено на развитие отдельных психических функций - мышления, памяти, внимания. Китайский язык, будучи принципиально иным по своим типологическим основам языком корневого типа с иероглифическим письмом, представляет собой известную трудность для российских студентов, зачастую изучающих лишь европейские языки агглютинативного типа с алфавитным письмом. Осознанное преодоление указанных трудностей китайского языка способствует формированию студентов, заинтересованных в собственном саморазвитии [4]. Мы глубоко убеждены в том, что в процессе преподавания китайского языка студентам экономических специальностей преподаватель должен учитывать их 
прежний опыт в освоении английского языка как первого иностранного и проводить сопоставление лингвокогнитивных механизмов, стоящих за обоими языками [5].

Роль педагога китайского языка чрезвычайно важна в условиях, когда предмет чрезвычайно сильно отличается от опыта, полученного при изучении других иностранных языков. При предъявлении лексико-грамматического материала преподавателю нередко необходимо подвести к проблеме, правилу, а не предъявлять его в готовом виде. Подобный подход позволяет студенту стать активным познающим деятелем, способным решать задачи, возникающие в ходе знакомства с многообразной китайской лексикой и грамматикой. В своем самом успешном варианте сотрудничество преподавателя и студентов призвано сформировать моделирующий и исследовательский тип познавательной активности, когда китайский язык станет проводником в мир особого незападного мира, успешно адаптировавшегося под западные стандарты глобального экономики [6].

В условиях пандемии COVID-19 педагоги столкнулись С необходимостью преобразования занятий очного формы в форму электронного обучения в дистанционном режиме с использованием он-лайн ресурсов. Цифровизация высшего образования имеет немало критиков и противников, но мы остановимся на очевидных плюсах данной инновации. Цифровизация позволяет сформировать принципиально новые контуры общения «преподаватель - информационная среда коммуникации - студенты», что достигается путем опосредованной компьютерной платформы для взаимодействия между субъектами, которые могут находиться в разных географических точках [7]. Интеграция в процесс преподавания китайского языка современных электронных сервисов не является исключительно необходимостью, продиктованной пандемией, а представляет собой цель, достижение которой позволяет сделать учебный процесс более эффективным, плодотворным и адекватным современным бизнес реалиям.

В предлагаемом цикле занятий выдвигается концепция занятий, направленных на постановку учебной проблемы и дальнейшее ее решение при помощи языковой догадки в процессе деятельностно-ориентированного учебного процесса. Реализация идеи о развитии языковой догадки на китайском языке проводится в сопоставлении с изученным материалом на английском языке. Студентам предлагается сравнить понимание объема дефиниций и значений фразеологических единиц с компонентами «животное», «зверь», а также анималистических языковых образов в китайском и английском языках. Результаты сравнения следует отобразить на дереве со словарными карточками на электронной платформе он-лайн коллаборации «Miro board» (рис. 1) [11].

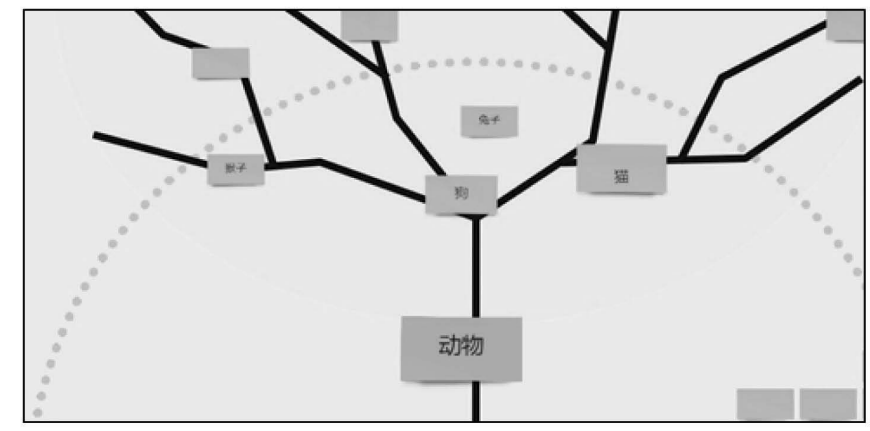

Рис. 1. Электронная платформа он-лайн коллаборации «Miro board» с промежуточными результатами цикла занятий по теме «Анималистические образы в китайском и английском языках»

Представим описание цикла занятий по заявленной проблематике. Цикл занятий включает в себя три этапа. Продолжительность каждого из этапов обусловлена уровнем группы, желаемой глубиной проработки дидактических и методических материалов. В ходе всего цикла представлена проработка репродуктивных и продуктивных видов речевой деятельности. Задания направлены на формирование критического мышления, раскрытие творческого потенциала, навыков микро исследования, а также формирование компетенций, связанных с синхронной и асинхронной работой в электронной среде в режиме совместного планирования и обсуждения проектной деятельности на глобальной платформе он-лайн коллаборации «Miro board».

Этап 1. Преподаватель создает ситуацию, в которой осуществляется рефлексивный анализ проблемного поля. Студентам предложено обсудить на китайском языке с использованием словарей объем понятий «животное», «зверь» и сравнить найденные словарные дефиниции в английском и китайском языках. В предложенных обстоятельствах студенты сталкиваются с проблемной ситуацией, когда несовпадение выявленных словарных дефиниций свидетельствует о необходимости более глубокого семного анализа китайских и английских лексем с учетом многообразия смысловых планов, специфики иероглифов [8]. Преподаватель фиксирует семантические расхождения на доске коллаборации «Miro board», формирует мотив к полному выявлению расхождений в объемах анализируемых понятий.

Этап 2. Преподаватель формирует проблемные группы студентов, изучающих фразеологический бестиарий на китайском и английском языках. Каждой группе поручено одно животное, фразеологизмы с которым необходимо проанализировать в сопоставительном режиме. На данном этапе на первый план выходит совместная деятельность учащихся, навыки работы в команде, необходимости распределения ролей. Учащимся необходимо сформировать гипотезу причин развития обра- 
зов, отраженных во фразеологии двух анализируемых языков. В ходе обсуждения генезиса образов возникает необходимость обращения к широкому историческому контексту, проведения диахронического анализа. Студенты осуществляют активную поисковую деятельность, формируют портфолио образов животных.

Этап 3. Этап презентации группами собранных материалов, иллюстрирующих образы животных в китайском и английском языках. Преподаватель на данном этапе осуществляет контрольно-фиксирующие действия. Представленные презентации размещаются на платформе он-лайн коллаборации «Miro board» и доступны для просмотра в любое время, как на самих занятиях, так и во внеаудиторные часы.

В ходе дискуссии о словарных дефинициях, выявлении сходств и различий в объемах фразеологических единиц на китайском и русском языках были выявлены следующие важные моменты. И в китайском, и в английском языках существуют сходные анималистические образы. В качестве примера обратимся к собакам, которые в обоих лингвокультурах являются домашними животными, преданно служащими хозяину и способствующими комфортному проживанию человека. Китайское выражение 犬马之劳 - собака и конь, верно служащие своему хозяину - подчеркивает значимость преданной службы, приписываемой домашним животным [9]. В английском языке находим аналогичное выражение: a man's best friend is his dog - собака есть лучший друг человека [10]. В рамках китайской лингвокультуры существует собственный бестиарный набор, в который входят тигры, жабы, птицы. Британскую и китайскую лингвокультуры сближает ряд выражений с компонентом «рыбы», что может быть объяснено их близостью к морю.

Предлагаемый цикл занятий призван обозначить перспективы обучения китайскому языку с опорой на знания по английскому языку, полученные еще на школьном этапе. Несмотря на типологические различия китайского и английского языков, в семантическом плане существуют важные направления для работы в сопоставительном аспекте, что свидетельствует о мировом родстве лингвокреативного мышления представителей разных культур и государств.

Соотношение этапов, индикаторов и результатов обучения

\begin{tabular}{|c|c|c|}
\hline Этапы и цели & Индикатор & Результат \\
\hline $\begin{array}{l}\text { Этап 1. Объем понятий «животное», } \\
\text { «зверь» в китайском и английском } \\
\text { языках }\end{array}$ & $\begin{array}{l}\text { Продуктивная дискуссия о коллокациях с } \\
\text { существительными «животное», «зверь». } \\
\text { Преподаватель стимулирует дискуссию, } \\
\text { задает проблемные вопросы, знакомит } \\
\text { с сайтами дефиниций и электронных } \\
\text { корпусов на китайском и английском } \\
\text { языках. }\end{array}$ & $\begin{array}{l}\text { Регулятивные. Синхронизация беседы, } \\
\text { создание проблемного поля. } \\
\text { Личностные. Актуализация фокуса } \\
\text { внимания, вхождение в проблематику } \\
\text { занятия. } \\
\text { Коммуникативные. Беседа на тему } 0 \\
\text { мире животных, активизация ранее из- } \\
\text { ученной лексики на китайском языке. }\end{array}$ \\
\hline $\begin{array}{l}\text { Этап 2. Работа в малых группах по из- } \\
\text { учению фразеологического бестиария } \\
\text { на китайском языке. }\end{array}$ & $\begin{array}{l}\text { Познавательная деятельность по вы- } \\
\text { полнению операций синтеза, сравне- } \\
\text { ния, классификации, доказательства, } \\
\text { коммуникации. }\end{array}$ & $\begin{array}{l}\text { Метапредметные результаты, связанные } \\
\text { с работой в команде. } \\
\text { Коммуникативные. Учебное сотрудниче- } \\
\text { ство в рамках обсуждения содержания } \\
\text { фразеологизмов. }\end{array}$ \\
\hline $\begin{array}{l}\text { Этап 3. Презентация подготовленных } \\
\text { материалов. }\end{array}$ & $\begin{array}{l}\text { Коммуникативные (представление со- } \\
\text { бранных данных). }\end{array}$ & $\begin{array}{l}\text { Регулятивные. Умение регулировать } \\
\text { действия во время презентации. } \\
\text { Коммуникативные. Учебное сотрудниче- } \\
\text { ство в рамках представления результатов. }\end{array}$ \\
\hline
\end{tabular}

\section{ЛИТЕРАТУРА}

1. Алефиренко, Н.Ф., Семененко, Н.Н. (2009) Фразеология и паремиология. М.: Флинта; Наука. 344 с.

2. Гудова, М.Ю., Гузикова, М.О. (2019) Модель полиязычного образования в университете: критическая теория грамотности и опыт Китая // Отечественная и зарубежная педагогика. № 2 (64). С. 186-199.

3. Завьялова, Н.А. (2015). Культурно-коммуникативные универсалии как современный этап развития культуры // Знание. Понимание. Умение. № 1. C. 77-88. DOI: 10.17805/zpu.2015.1.7

4. Завьялова, Н.А. (2016). Повторяющиеся культурные микроконтексты: диахронный и синхронный аспекты//Знание. Понимание. Умение. № 2. С. 124-137 
5. Карасик, В.И. (2009) Языковые ключи. М.: Гнозис. 406 с.

6. Костина, А.В. (2008) Тезаурусный подход как новая парадигма гуманитарного знания//0бсерватория культуры. № 5. С. 102-109.

7. Луков, В.А., Луков, Вл.А. (2008) Тезаурусы: Субъектная организация гуманитарного знания. М.: Изд-во Нац. ин-та бизнеса. 784 с.

8. Орлова, Э.А. (2010) История антропологических учений: учебник для студентов пед. вузов. М.: Академ. Проект; Альма Матер. 621 с.

9. Пелипенко, А.А. (2011) Дуалистическая революция и смыслогенез в истории / предисл. А.С. Ахиезера. 2-е изд., испр. М.: Книжный дом «ЛИБРОКОМ». 384 с.

10. Томберг, 0.В. (2020) Диалогизм и культурный трансфер в древнеанглийской поэтической традиции. Вестник Московского городского педагогического университета. Серия: Филология. Теория языка. Языковое образование. № 3 (39). С. $70-78$.

11. Платформа он-лайн коллаборации «Miro board» (Электр. ресурс). Режим доступа: https://miro.com/app/dashboard/ (Дата обращения: 11.03.2021)

() Завьялова Наталья Алексеевна (n.zavzav@yandex.ru ), Ли Синьци, Юань Мэнмэн.

Журнал «Современная наука: актуальные проблемы теории и практики»

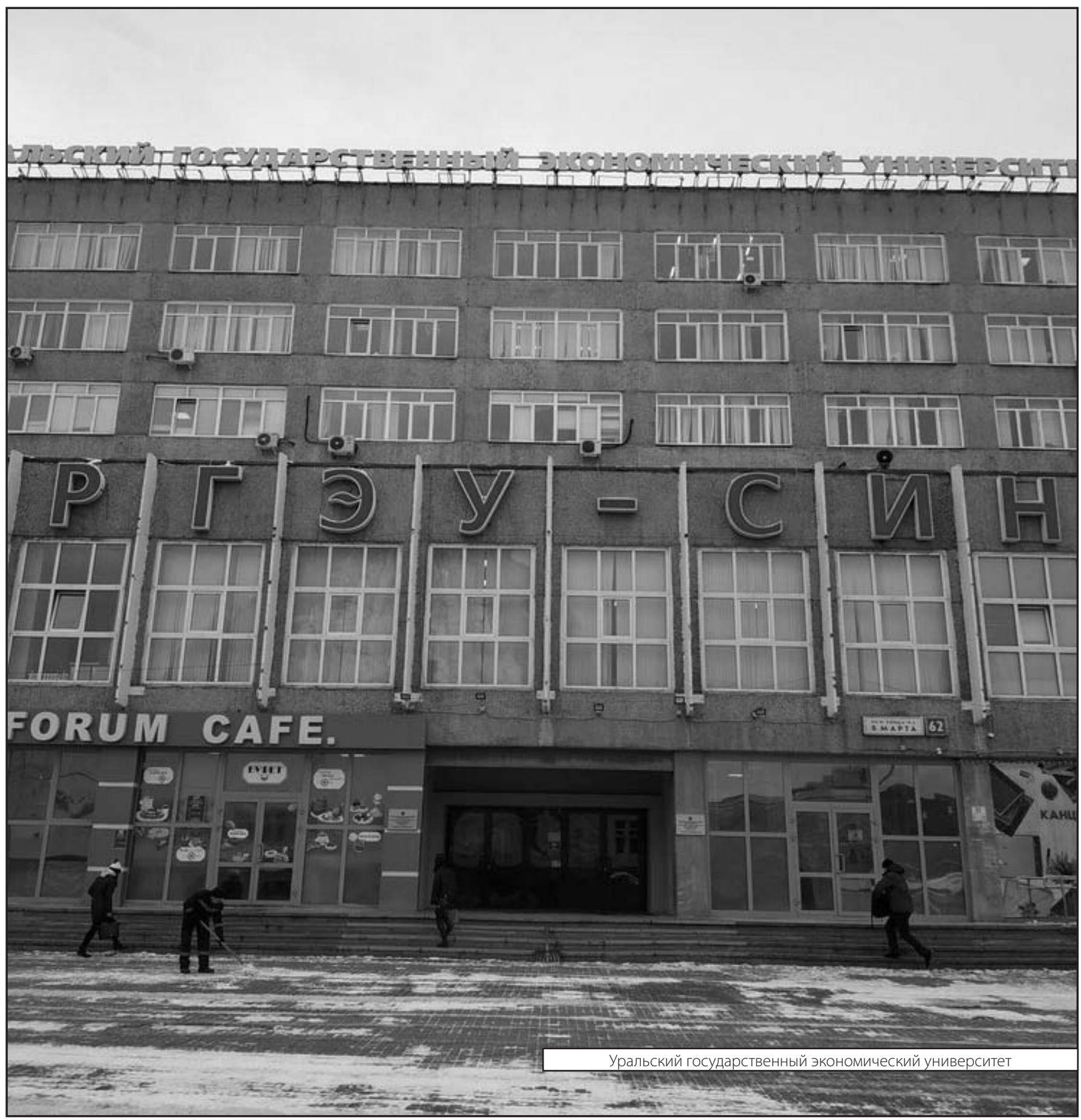

